\title{
Exacavating the Memory of Slavery in Léonora Miano's La Saison de l'ombre (2013) and Toni Morrison's Beloved (1988)
}

\author{
Abib SENE \\ Department of Anglophone Studies, Faculty of Arts and Social Sciencs, \\ Cheikh Anta Diop University,Dakar, Senegal \\ abib.sene@ucad.edu.sn \\ senabb2@yahoo.fr \\ Fatoumata KEÏTA \\ English Department, Université des Letters et des Sciencs Humaines Bamako-Mal, \\ fatoumatakeitafr@yahoo.fr
}

DOI: http://doi.org/ 10.36892/ijlls.v3i3.662

Received:

03/08/2021

Accepted:

15/09/2021

Keywords:

Slavery, Trauma,

Motherhood,

Memory, Catharsis,

Slave Narratives,

Responsibility.

\section{Abstract}

Regarded as a state of servitude through which an individual or a group of persons is compelled to work their guts out without any possibility to get compensated or rewarded, slavery, for some centuries, had been implemented under various forms from one country to another. From the antiquity to the twentieth century, thralldom had been a profitable business that gangrened the African continent. Thus being, African and African American thinkers shoulder the mission to dust archives and lift the curtain of history to retell and re-narrate the episode of drudgery; among them Leonoa Miano and Toni Morrison. The purpose of this article is to examine the trauma of slavery from a comparative, matrifocal, and Afrocentric perspective so as to highlight commonalities and differences between Leonora Miano's La Saison de l'ombre and Toni Morrison's Beloved. Inspired by the infamous history of slavery, these two award-winning novels not only conjure up the ordeal of slavery, but they also catalyze its haunting memory for the sake of healing, so that both characters and readers could be cleansed off its tantalizing grip and achieve catharsis and redemption. To this end, La Saison de l'ombre and Beloved are woven around feminine counter-narratives that exhibit countermemories which are often glossed over or overlooked in both African and Euro-American phallocentric official narratives. Whereas La Saison de l'ombre spotlights the Africans' role in the process of slavery, Beloved highlights the tragedy of a maternal love in a context of bondage. Through a comparative approach, we have spotlighted the whole process of slavery, from the captivity in Africa to enslavement in America.

\section{INTRODUCTION}

Literature from Africa and the African Diaspora is often focused on the historical damage of slavery on the African culture, body, mindset and imagination. Many novels were cast in the mould of the older slave narratives which were the true accounts of slavery from the standpoint of the slaves themselves. However, the early slave narratives shed light more on the institution of slavery and its inhumanity than the personal grieves, pains, and trauma of the individual slave.

Parallel to Yambo Ouologuem's Bound to Violence and Soyinka's A Dance of the Forest, La Saison de l'ombre is a historical narration that goes against the traditional correctness of the African historical novel that presents Africa as an eudemonic place doffed 
of any misfortune where indeed traditional communities would live and evolve into a life style that would epitomize a paradised existence. Leonora Miano, in her capacities as a young African writer, tears the curtain of bashfulness on the matter of slavery to yap about the central responsibility of feudal Africa in the process of slavery. La Saison de l'ombre is a story that fingers out the tragic destiny of a continent harassed by a vice grip stretched by the Western negriers and the autochthons' collaborators. As a consequence, the black youth appears as a prey to hunt, a staff to merchandize, a labour force to exploit. Men and women become receptacles of misfortune, expressions of bad luck and tears of hopelessness. It is in such a context that Toni Morrison, in her novel Beloved, pinpoints the cruelty of slavocracy in America. Engaged to tell the story of enslavement to the younger generation, the author of Sula, fictionalizes a world in which the narration of the lives and death of its characters drums the dramatic side of slaves' lives in the Southern coast of America.

This study envisions to show how these two prolific novelists fictionalize history by giving prominence to the maternal narratives of pain and trauma triggered by the memory of slavery. Emphasis will be laid on the way women conjure up the memory of slavery so as to bear their onus of responsibility to the dead and the missing ones, and finally cleanse themselves off the tantalizing grip of the past for the sake of achieving healing, catharsis, and redemption.

\section{LITERATURE REVIEW}

The problematic of slavery has always been a source of inspirations for many African and non-African writers. In his work titled "Slavery in Africa. Historical and Anthropological Perspectives"(Klein, 1977), Martin A. Klein, in an exquisite style, has presented the horrorstriking events and steps that characterized slavery in a postcolonial Africa. In his objective to adduce information on responsibilities of Western and African actors, Klein highlights the role the African traditional chiefs played as slaveholders in the process and the enactment of slavery as in Africa. He then makes a link between the practice of slavery, tribalism in Africa and later on colonialism. His work is echoed in Mahameed Mohammed's article "The Impact of Slavery in Toni Morrison's Beloved: From the Communal to the Individual". In this paper, Mohammed insists on the psychological and physical trauma inflicted on black people in days of slavery in America. He as well depicts the memory of slavery which indeed defined the victims as beasts of burdens that eke out a modicum of normal life.

Like Beloved, A Mercy (2008) also plunges the reader headlong into the tragedy of slavocracy cay. As a neo-slave narrative, it casts a new and fresh light on the atrocities of slavery from a mother-daughter perspective. In this regard, Beloved differs from other neoslave narratives like Ishmael Reed's Flight to Canada (1976), Shirley Anne's Dessa Rose (1986) or Charles Johnson's Middle Passage (1990) which resort to the "conventions and strategies of the antebellum slave narratives to write in the voice of manumitted fugitive slaves" (Rusdy, 1999, p. 6) with the aim "to salvage literary form of the slave narratives from what was generally thought as its appropriation in the sixties" (Rusdy, 1999, p. 6 ). Beloved differs from these coeval accounts and it foregrounds loss and sorrow, trauma and healing with characters striving to break loose the fetters of their haunting past" (Keita, 2014, p. 11. ). Besides, Morrison "wanted to explore the nature of slavery, not from an intellectual or slave narrative perspective, but from within the day-to-day lived experiences of the slaves themselves" (Mckay, 1999, p. 7). Furthermore, contrary to novels like Amistad by Joyce Annette Barnes (1998) and Moi, Tituba sorcière by Maryse Condé (1988), which insist on the Middle Passage, La Saison de l'ombre by Léonora Miano puts the focus on the responsibility, if not the contribution of Africans to the success of slaves-captures in Africa; a theme that has not been so far enough dealt with by African and non-African thinkers.

\section{UNPACKING A FEMALE BUNDLE OF MEMORY: PAIN AND CONTRITENESS OF A TRAUMATIC EXPERIENCE}


Dione describes the slave trade as "one of the most historical tragic events humanity ever experienced." (Dione, 2009) From the Latin word "slavus", the term "slave" stands for an individual who is abducted of his or her human rights and walled off in a slant of a chattel or belonging of a wealthy, noble birth or a high-social standing master. Inborn and corporate in the African social fabric, slavery had been a practice upped and done in various social contexts related to wars, raids, kidnapping, marriages, etc. Indeed, that practice took a whole new dimension with the arrival of European missionaries who were the successors of Arab merchants. Slavery not only robs the African people of their humanity and dignity, but it as well casts shame and disgrace on them and their descendants. This dark historical period sets the story of La Saison de l'ombre by Miano where the primary arc of the plot is woven around the issue of selling and buying human beings. Indeed, during three centuries, millions of healthy and strong Africans would be forcibly wrenched off their motherland and shipped away to America for the sake of exploitation of various kinds. The Middle Passage not only severed the umbilical cord between Africa and its Diaspora, but it wiped out many ingredients of the African past in the mind of the slaves who suffered a traumatic backlash from this cultural genocide.

Present in the coast of le pays des Eaux, the Negriers, in common agreement with the Bwele people, set their choice on the Mulango populations who, so far, have been living in peace and harmony with their neighbors. Through a criminal fire, case provoked in the Mulongo's territory, the Bwele capture a dozen of young villagers to sell them to the Whites slavers who settle their headquarter in the coast. Unaware of foreign presence in their vicinities and the Bwele's new vision of the world and new munching mentality, the Mulongo accuse the victims' mothers of witchcraft. In fact, the women whose sons are captured and sold, are also accused of shadowing them (Miano, 2013, p. 37), meaning bewitching their own children. To punish women, the guardians of traditions cage them in a small and isolated room where they are condemned to pull long faces, mourning and moaning on the cruel destiny their sons have gone through. Accordingly, the narrator voices their silence, which indeed, becomes, in the eyes of the community, a negative object the guilty women have to be in conjunction with so as to purify their 'wrong' 'deed'. They are made to pay for a crime committed by the African men who turn themselves into slave sellers. The room in which they are gathered is then described as a custodial space where their presence appears as a subtext, a synecdoche that identifies women as samples of undesirable and disempowered beings of those who have gone bonkers because of set beliefs and traditions. Eyabe, one of the caged women, comments on their plight in these words: "now, the shadow is what we have to make do with. It has replaced the daylight for us (Miano, 2013, p. 27). Those whose sons have disappeared becomes the moniker, the nickname through which the misfortune ladies are identified. The community to which they belong deprived them of their freedom of movement, correct diet, and any other form of social rejoicing. Eyabe protests in the following: "we did nothing wrong. We did not bewitch our own sons and nobody has a right to treat us like criminals" (Miano, 2013, p. 26)." Whilst the so-called guilty women in La Saison de l'ombre are condemned in an exilic existence in a cage from where a bird cannot sing, in Beloved, Sethe and Denver live in a house "Suspended between the nastiness of life and the meanness of the dead" (Morrison, 1988, p. 9). Miano gives a voice to women martyred by a male and phallocratic society. However, women speak but are not listened to. The society in which they evolve is male-dominated sodality through which women live like shadows with no powers of decisions or authorities. Like Miano, Morrison tears the veil of female silence in the context of slavery to free the voice of the enslaved and dehumanized woman. Commenting on her narrative project in Beloved, Morrison writes in 'The Site of Memory': 
[ for a] writer who is black and a woman, writing fiction is very different in that, more than the authors of the slave narratives did in the past, she is interested in how to rip that veil drawn over "proceeding too terrible to relate". The exercise is also crucial for any person, who is black, or who belongs to any marginalized category, for, historically, we were seldom invited to participate in the discourse even when we were its topic (Morrison, 1977, p. 293).

Beloved differs from the early accounts of slavery in that its target and implied readers are first and foremost Blacks themselves. The novel warns both Blacks and Whites about the danger of putting one's history under erasure, the danger of shirking one's onus toward the past and the dead. For, eschewing one's past is tantamount to bury one's head in the sand. As John Edgar Wideman relevantly posits:

Past lives in us, through us. Each of us harbors the spirits of people who walked the earth before we did, and those spirits depend on us for continuing existence, just as we depend on their presence to live our lives to the fullest (A. Rushdy, 1992, p. 67).

Baby Suggs further adds that: "death was nothing but forgetfulness"(Morrison, 1988, p. 04). Actually, as long as the dead are remembered, their spirits will remain on the continuum of life. To Sethe, and by implication all Blacks, as Morrison attests, "the future was a matter of keeping the past at bay." (Morrison, 1988, p. 51). Since its publication in 1988, Beloved has attracted a steady critical attention and accolades as well as a wide national and international fame. Beloved was written to address a historical gap in American history, the absence of memorial site for slavey. She explains this gap in the "A Bench by the Road" as follow:

There is no place you or I can go, to think about or not think about, to summon the presences of, or recollect the absences of slaves; nothing that re- minds us of the ones who made the journey and of those who did not make it. There is no suitable memorial or plaque or wreath or wall or park or skyscraper lobby. There's no 300 foot tower. There's no small bench by the road. There is not even a tree scored, an initial that I can visit or you can visit in Charleston or Savannah or New York or Providence or, better still, on the banks of the Mississippi. And because such a place does not exist (that I know of), the book had to (quoted in Mc Kay, 1999, p. 3).

The novel was analyzed from a spiritual perspective as a ghost story relating the return of the past for the sake of remembering as atonement (Holloway, 1990; Krumholz, Harris, 1991; Henderson; 1991; Rushdy, 1992; Handley, 1995), but also a postmodern narrative blending magical realism and fantasy (Pérez-Torres, 1999; Ramzi, 2012; Abdullah, 2015). It must be noted that “ Toni Morrison's fiction has been interpreted through the lenses of various theoretical and critical perspectives encompassing and overlapping sundry disciplines. From the gothic to the grotesque, the postcolonial to the postmodernist, to the gendered and the apocalyptic, critics have infused her art with a myriad of signification, insights and aesthetic conjectures. Of all her novels, Beloved seems to have attracted the most impassionate critical debates" (Keita, 2018, p. 49). Memory weights large on the narrative tapestry and constitutes one of its important layers. Both the novel and the eponymous characters, catalyze the memory of slavery, its physical and psychic trauma endured by black women and men from the Middle Passage to the American plantations. As the living incarnation of slavery and its repressed memories, Beloved ignites the process of remembering, redemption, and catharsis. Her plight casts a new light on black women's 
inconsequential sacrifices during slavery. Indeed, Baby Suggs has eight children and ends up with none; Sethe's mother throws all her babies, except Sethe herself. Morrison's version of history is then a matrilineal, feminine one, laden with generational stories of infanticide and dramas. Hence, Morrison's revisionist historiographic project which, in Beloved, involves, according to Mae Henderson, a double agenda that consists of "the exploration of the black women's sense of self and the imaginative recovery of black women's history" (Henderson, 1999, p. 83).

Contrary to Miano who opposes two black communities that smack one another, Morrison articulates a story that mirrors the trauma of a matrilineal family left to fend for themselves. Torn apart by the double yoke of blackness and womanhood, Sethe and her daughters in Beloved, like Eyabe and her likes in La Saison de l'ombre, fumble for liveable lives in a stark era where being black is akin to being a social scrap that means nothing if not good to be sold, bought, exploited and demonized. Importantly, Beloved is a story of loss and sorrow, trauma and healing where the characters strive to break out from the fetters of the tantalizing grips of their past. However, that past never passes; it keeps on coming back in the form of a haunting baby who wreaks havoc in the two women's lives. Knowing that, her past had been like her present - intolerable, Baby Suggs "used the little energy left to her for pondering color" (Morrison, 1988, p. 04). She is a survivor of the worst of slave life which "busted her legs, her heart - which she put to work at once" (Morrison, 1988, p. 102). Stiffen into a system of the slavocracy, Baby Suggs's family live in miserable places where their lives are confiscated and their humanities barbarized. Like women in La Saison de l'ombre, who are confined in a physical cage, hermetically sealed, women in Beloved are also fettered in the prison-house of memory, where "rememory" harks back their painful and infamous past. Consequently, in both novels, women are entrapped and oppressed by social forces. They are rendered powerless and weak in a world where the laws of the strongest reign. Beloved gives flesh to female suffering and makes more audible the trauma that female slaves undergo in their journey to America. Like Léonora who paints a tragic female universe in $L a$ Saison de l'ombre, Morrison draws aside "the metaphorical veil to re-appropriate the past of her people" (da Anpoll, 2007, p. 160), highlighting, therefore, the possibility of mourning for her black community through remembering the dead and providing them a decent sepulture. Beloved is the catalysis of this memory and paves the way for healing and atonement.

Moreover, in Beloved, female memory is also laden with the pain and shame induced by sexual violence, another consequence of the slavocracy. In the novel, the pervasive presence of rape is ascribed to White men. Ella is raped by her white master and his son whom she refers to as 'the lowest yet.' Baby Suggs as well is forced to have sex with her master so that her children will not be sold away and Vashti, Stamp Paid's wife, was raped by her master. These instances constitute only the tip of the iceberg. The profusion of rape in the novel is closely intertwined into the economy of slavery which legalizes the use of the slave body as a chattel, a commodity that can be sold or bought in the auction block, and raped according to the master's whims and fancies.

"In order to draw aside the metaphorical blanket and re-appropriate the past of her people in her writings, Morrison claims it necessary to trust not only her own recollection but also the recollection of others"(da Anpoll, 2007, p. 160). She then, as a storyteller, breaks open the tragic past of her Black fellows and itemizes the traumatic lives slaves go through. Like Morano, who revisits the bygones of the slavery in the swampy pages of the African continent to break taboos of a sad and cruel history, Morrison bluntly writes naked the imprisoned destiny Blacks, specifically, black women, are enchained with. In Beloved, the author of Home defends the sanctity of black motherhood and the mother-daughter dyad. As a wife, mother and grandmother who spent sixty years in bondage, Baby Suggs emerges in her free years with two cogent lessons which she bequeaths to her daughter-in-law, Sethe, and her granddaughter, Denver. The first lesson is: "there is no bad luck in the world but 
white people. They don't know where to stop." (Morrison, 1988, p. 122-123). According to Suggs's principles and understanding of human nature, "everything depends on knowing how much, and good is knowing when to stop" (Morrison, 1988, p. 102). Her second lesson is that: "a man ain't nothing but a man. But a son. That's somebody." (Morrison, 1988, p. 27). These assertions find their justification in Suggs's forlorn existence. Being husbandless for years, because the system of slavery denies women a social and family life, she is freed by her only remaining son, Halle.

Furthermore, in Beloved, women bear the signs of history. It is written in their bodies and psyche like indelible historical stamps or signposts. Sethe has a tree in her back, a 'chokeberry tree' according to Amy Denver, and a 'haint in her house'. This tree is a symbol and a nail-biting testimony of a genealogy of suffering and flogging under the fetters of slavery. Sethe's mother bears a fire mark. Denver, Ella and Beloved also carry their physical and internal scars like crosses. The author disavows the legitimacy of Western historiography which is couched in a biased representation of African Americans. Her characters are dynamic historical agents who wreak havoc in order to make their voice heard in a dominating and domineering white society. Moreover, in Morrison's work, the past is not discrete dated events recorded in books; rather, it is linked to places, pictures and natural elements. Africa and South America constitute the repository of the past. In Beloved, she imagines a slave ship as a reminder of the characters' African background and origin.

Whereas Morrison deals with a daughter-mother dyad, Miano is interested in a mother-son twosome. If in Beloved, the daughter-mother couple is tormented and dislocated by Whites who "do not know where to stop"(Morrison, 1988, p. 122-123), in La Saison de l'ombre, the Mulango community is harassed and traumatized by their fellow Blacks, the Bwele people, whose first and unique lesson is to kidnap local villagers and sell them to Negriers.

In both novels, pain and sorrow are feminized to the extent that women stand as a social category whose particularity is labelled: neither dead nor alive. In the context of war between the North and the South, Baby Suggs, and her daughter-in-law and granddaughters are subjected to a withering way of life that deprives them of their dignities as human beings. Beleaguered and permanently abused by their masters, Sethe and his/her/their family are given a flat refusal to have access to humanizing values.

If Eyabe and her followers are denied any social status in their own community, Sethe and her fellows are disposed of their sense of belongingness. In both Beloved and La Saison de l'ombre, female characters are soothed into un-naming and misnaming, loosing therefore their identities as humans and as women. In so being, women do not have names anymore. Their identities are erased and a nickname is articulated to designate who they are and how far they are isolated and rejected out of their communities. Actually, in Beloved slave women are renamed by their masters who, for the sake of domination, alter their selfhoods as human beings. They belong to their owners and are to content themselves with what the former give them as status and identifiers.

La Saison de l'ombre and Beloved link the phenomenon of slavery to the issue of identity and naming. The name one bears, in the context of enslavement, has much to do with one's humanity or inhumanness. With an Egyptian origin, the name Sethe is reminiscent of and refers to the god of confusion. Beaten and manhandled by her boss, Sethe loses control and fades into confusion and total turmoil. Her life and that of her beloved ones are named out of normalcy. They are muddled (Sethe) they are hogs (Baby Suggs), etc. Insanity and animality are what slaves stand for in the eyes of the slavers. They become objects, nonentities that exist in anonymity.

Parallel to Beloved by Toni Morrison, women in La Saison de l'ombre, whose sons are sold to the Whites in the coast, are dispossessed of their nominal identity. Nobody in their community calls them by their names. Their byname becomes collective and unified through the one and single fragment: 'those who have lost their sons'. In a similar vein, women in 
Beloved are objectified. From visibility, they are moved into invisibility. From human status, they are turned into junk-caged. Morrison's revolutionary and feminist stances rest squarely on her adeptness to relocate black women at the center of both history and narrative. Interestingly enough, Beloved proffers an agency and a voice to the female characters so that they become the articulators of a hidden, infamous, and tainted history.

It is important to note that one of the aims of ethnicity is not only to set up an acceptable past for the group but also to ensure reconnection and bonds with the ancestors. Morrison achieves this by ferreting out the arcane of the past, the vestige of memories burrowed beneath the recesses of Blacks' minds. In doing so, she endorses Linda Anderson's view according to which: "writing history (as historical novels and in other forms) is one way for marginalized peoples to counter their invisibility" (Peterson, 1998, p. 177). Hence, Morrison's reconstruction and revision of history is a battle against the invisibility of both her ethnic group and women as well, since both occupy liminal space in the mainstream narratives. She tabulates Western linear narratives and replaces them with an oral circular one, using ethnicity as a strategy to disrupt binary opposites such as master/slave, oppressor/oppressed, colonizer/colonized, or definer/defined.

Leonora and Morrison have dramatized female pain and dehumanization in the process of slavery. Forsooth, women are reduced to mere shadows that speak the language of silence and muteness. While Morrison focuses on the lives of those who are deported to America, Miano puts stress on Africans' responsibilities in the process of slavery. Though Sethe and her family members' lives become hellish, those of the women whose sons are sold into slavery have collapsed apart. In both novels, women are traumatized at will and muzzled in the name of their being nonentities.

\section{BEARING RESPONSIBILITY: ATONEMENT, HEALING AND REDEMPTION}

Regarded as being one of the most tragic events in Mankind's history, slavery has been a cornerstone of the reflexion on Africa and Africans. In La Saison de l'ombre, Miano puts on the surface the tragedy provoked by Africans upon their fellows Africans to perpetuate the slave trade with hen's-like men. Reminiscent black slave-sellers, the Bwele people set fire, mutilate, kill and sell Blacks to the foreigners.

Toni Morrison who, in like manner, is a prominent writer, has transformed the sorrow and inner trauma of her black characters into a meaningful lesson that transcends the boundaries of race, ethnicity, sex, and religion. Her attachment to her black community and her willingness to give flesh to their lived experiences, undoubtedly, alchemize her literary texts into real pamphlets against social injustice and repression. She gives room to black mothers with their "anti-slavery mindset" (Poorghorban, 2020, p. 43) to bear witness to their untold suffering and psychic pains.

It is worth mentioning that black women writers have always displayed a vested interest in the image of black motherhood. Having grappled with years of stereotypes, they now face the challenge of representing a more positive image of mothers and their wrench of parting with their children during slavery. Yet, what makes Morrison's novels remarkable is that they give primacy to mothers, opening a window for them to give vent to their sorrows, anger, and hopelessness. She allows them to air their innermost feelings in a society where their status is shaky and cloaked with oppression and exploitation. As a matter of fact, Morrison's novels are characterized by the presence of strong maternal figures and a relative absence of fathers. In Beloved, there is a female trio (grandmother, mother, and daughter), and a powerful bond between them. Sethe appears as a strong and independent mother. Denver reports that her mother "never looked away when a man got stomped to death by a mare right front of Sawyer's restaurant" (Morrison, 1988, p. 104). However, such a portrayal of black women is prone to lend force to the myth of the 'super woman' which expects black 
women to fulfill multiple roles and bear sundry forms of abuses and problems uncomplainingly. But Morrison's merit rests on their critical evaluation of the motherdaughter bond and the common held myth associated with motherhood itself.

Nevertheless, the profusion of infanticide and cruel death in her fiction might question the credibility and humaneness of black mothers, and thereby bolster up the very myth Morrison strains so hard to dismantle. For instance, Eva Peace in Sula burns her son, Plum, alive under the ground of saving "his manhood," and Sethe kills Beloved in order to save her from slavery. Both acts are triggered by mother love and concern. Yet, the novels seem to pose but not resolve the legitimacy of such infamous acts.

In Beloved, Sethe's story is a moving litany of drama and sacrifice. She weaves an ineffable narrative, tarnished with the spectrum of infanticide. In point of fact, Sethe's discourse bears the imprint of centuries of oppression, sorrows and shame imposed on slave mothers. Her plight harks back with a nail-biting irony the peeve underwent by Aunt Chloe, Eliza, Patience, Susan, Cassy and all those nameless slave mothers of Harriet Beecher Stowe's heart-wrenching novel, Uncle Tom's Cabin (Beecher Stowe, 1852). But, what is interesting is that she is allowed to narrate her story and be atoned of her crime and guilt. By circling over the story, musing it and finally retold it, she achieves catharsis and redemption. She unburdens her pain by bearing responsibility for her crime. In most novels, it is the daughter's plight that is put in the forefront, while the maternal discourse is either muffled, or simply mediated through another voice. In Beloved, Sethe's story is a moving litany of drama and sacrifice. She weaves an ineffable narrative, tarnished with the specter of infanticide. The narrator reports: "Sethe knew the circle she was making around the room, the subject...that she could never close it, pin it down for anybody who had to ask. If they didn't get it right off- she could never explain it." (Beloved, p.192). Her story fits in Hirsch's contention that: "the mother's discourse, when it can be voiced at all ...is a story 'cruel enough to stop the blood" (Hirsch, 1990, p. 426).

Miano and Morrison interrogate the past to re-read history with magnifying glasses. Indeed, in La Saison de l'ombre men and women who stand up to path their ways to the coastal region to find back Mulongo's lost young people, have gone through hash treatments in the hands of the collaborators, who put no mind in the brutality they hinge upon their fellows Africans. They engage their imperatives in highlighting a dysphoria aspect of their exactions. The forms of mutilation the local population go through in La Saison de l'ombre aims at silencing the Mulango community forever. He who has discovered the truth and the betrayal of his neighbors loses a right to speak. And he who loses the ability to speak becomes a beastie. So Africans animalize other Africans for cast-offs and trinkets.

Similar to the kidnapped young villagers in La Saison de l'ombre, slaves in Beloved are followed through the Middle Passage which is described as a journey to a bilious and dyspeptic life, a cultural genocide. Drink piss, ironed necks, sticking with dead bodies, are the horrific images that go hand in glove with Middle Passage and Slave Trade.

Once in destination, slaves become mere chattels, goods to be owned and sold by their masters. Women, for their part, become sexual prey and beasts of burden. That life of nobodiness brings Sethe who has been going through slavery for years to commit a sound and moving act. She kills her own daughter to save her from the grip of slavery. Putting a special notice on black bodies, Beloved is the expression of a repressed evil. It quantifies and symbolizes the bridge between death and life. In so being, "Morrison attests, through the reincarnation of a killed girl, the persistence of racist violence fueled by slavery" (Durkin, 2009, p. 176).

In addition, the African American writer juxtaposes both accounts of official historical documents and the oral reports of the slaves themselves, thereby reviving the longwinded debate of literacy and orality. She declares that the story of Beloved was inspired by "two or three little fragments she had heard from places" (A Rusdy, 1992, p. 569). One of these stories was the true story of Margaret Garner, a runaway slave who found refuge in 
Cincinnati in 1856. Because of the Fugitive Bill that allowed run-away slaves to be captured whatever their refuge, was she chased by her owner. The latter's attempt to capture her and her family led to the infamous act of infanticide. She cut the throat of her little daughter rather than let her go back to bondage and a life-long suffering (O'Reilly, 2004, p. 569). This historical event constitutes both the subsoil of Beloved and its underpinning theme. Sethe, too, chooses death for her two-year-old daughter rather than the mercantile system of slavery when she murders her. In Beloved, women bear the signs of history. It is written in their bodies and psyche like indelible historical stamps or signposts. Sethe has a tree on her back. This tree is a symbol and a nerve-wracking testimony of a genealogy of suffering and flogging under the fetters of slavery. Sethe's mother bears a fire mark. Denver, Ella and Beloved also carry their physical and internal scars like crosses.

Morrison's minute and painstaking depiction of slave life in this novel find its corresponding in La Saison de l'ombre. If Seth and her fellows bear tree and other signs of history on their bodies, The Mulango women anoint themselves with white mud as a sign of moaning. If the Bwele kill to dominate and sell their likes, Sethe kills to save and free her ilks. Beloved becomes therefore a kind of reincarnation of ancestors tortured, captured and slain or sold in the Mulongo's land to slave-owners. Her death is the restored bridge that links the world of the living and that of the dead.

Both narrations trail the itineraries of 'slavocracy' to centralize the responsibilities of Africans and the traumatic side of human dispossession. It comes to be said that slavery, as it is described in the novels understudy, is an unspeakable and unspoken heavy-handed human blunder. Hence the urgency for Africana women writers like Toni Morrison and Léonora Miano to take a reverse crossroad by undertaking a 'Middle Passage back' in their imaginative works which re-member this thorny and gloomy page of Blacks' history. In this regard, Morrison's Beloved and Miano's La Saison de l'ombre revisit and re-imagine slavery by opening its pandora box. As modern fictional slavery narratives, they shed light on the horrific legacies of slavery by forcing their readers to hark back and bear their full accountability for this nefarious practice.

In Beloved, the author defends the sanctity of black motherhood and the motherdaughter dyad. She rails against any form of hegemony or oppression that breaks the sisterhood between women. In the above mentioned novel, the female characters develop an ethos where they live in oneness with themselves and the culture and nature that give them life and sustenance. With eye-catching wisdom and grace, Morrison tackles the thorny hurdles black mothers come up against in America and how their plight is interlocked into the broader history of their race. She, searchingly, captures the searing drama of these mothers and their complex and ambivalent feelings toward their offspring. Despite the damage wrought by slavery in their lives, they try to preserve their maternal privileges and duties toward their children. However, in her seminal book, Toni Morrison and Motherhood, O'Reilly attributes the damage of African American mothering and maternal practice to slavery which not only denies black people humanity but prevents them from reclaiming their history. ${ }^{1}$

\section{CONCLUSION}

Leonora Miano and Toni Morrison have lifted the taboo curtain to let us see what so far has been dogged by human consciousness. They put on the surface the ins and outs of a gloomy past that gangrened the lives of men and women both in Africa and America.

Miano, through La Saison de l'ombre has highlighted enough the key role played by Africans themselves in the success of the enterprise of slavery. She portray all the same a

\footnotetext{
${ }^{1}$ Andrea O'Reilly. Toni Morrison and Motherhood: A Politics of the Heart, op.cit., p.74.
} 
high-pitched trauma experienced by victims' mothers who, in spite of their innocence, are taken aback and left with no choice but to mourn and shed tears. As for Toni Morrison, she has plainly described the destiny of those who are sold on the other side of the Atlantic. A way of finding the right center in terms of historical responsibilities in the process of slavery from Africa to America.

Beloved raises ethical issues related to love and its significance. The stories beckon the reader not to pass judgment, but to muse about the meaning of love in the life of black people. It poses the question of the legitimacy of Sethe's 'thick love' in a despicable slave system that denies Blacks any form of humanity.

Importantly, La Saison de l'ombre and Beloved explore the complex question of slavery and its outcome. They express the necessity of confronting the memories of slavery in a harmless and digestible manner. In her attempt to reconstruct and retell the gloomy edges of African History, Miano digs up the traumatic side of slavery Africans experience in the African continent. She, as well, in a clear-cut position, underlines the African responsibility in the morbid process of slavery. From Africa to America, the slaves are dehumanized by both black and white actors. The two authors embody texts which in turn give pulpit to a soul of a past made of pain and a present haunted by a history of oppression and massacres. The two historical novels tell the stories of men and women to describe the wounds carried by Africans in Africa and America.

\section{REFERENCES}

Ashraf H. A Rusdy. (1992), "Daughters Signifyin(g) History: The Example of Toni Morrison’s Beloved' 'In American Literature, vol.64, n³.

Beecher Stowe, Harriet. (1852), Uncle Tom's Cabin or Life Among the Lowly, Boston: John P. Jewett \& Company.

Da Anpoll Revisita, Azevedo. (2007), “Toni Morrison's Site of Memory where Memoir and Fiction Embrace” In Mail Marques, num 22.

Dione, Abdoulaye, Le Voyage atlantique et la traite des noirs dans la littérature ouest africaine anglophone du Nigeria et du Ghana, Thèse de doctorat unique soutenue en juin 2009 à l'université de cergy-Pointoise.

Durkin, Anita. (2009), “Object Written, Written Object: Slavery, Scarring, and Complications of Authorship" In Toni Morrison's Beloved, Bloom's Modern Critical Interpretations: New York.

Henderson, Mae. (1999), “Toni Morrison's Beloved: Remembering the Body as a Historical Text", In Toni Morrison's Beloved: A Case Book, New York: Oxford University Press.

Hirsch, Marianne. (1990). "Maternal Narratives: Cruel Enough to Stop the Blood.' In Reading Black, Reading Feminist: A Critical Anthology.(Ed.). Henry Louis Gates, Jr., New York: Meridian, pp.415-430.

J. Peterson, Nancy. (1998), "History, Postmodernism, and Louise Erdrich's Tracks' In Contemporary American Women Writers: Gender, Class, Ethnicity, New York: Addison Weslet Longman.

Keita, Fatoumata. (2014). "From Love Ethic Ethic to EthicalAgency: Toni Morrison's Love Poetics in Beloved and Song of Solomon." SAFARA : Revue Internationale de Langues, Littératures et Culture, $\mathrm{N}^{\circ} 13$, Pp. 5-24. 
Keita, Fatoumata (2018). : "Conjuring Aesthetic Blackness: Abjection and Trauma in Toni Morrison's God Help the Child."Africology: The Journal of Pan African Studies, vol.11, no.3, pp. 43-55.

Klein, Martin A. (1978). "The Study of Slavery in Africa”. In The Journal of African History, 19 (4), pp. 599-609.

Miano, Léonora. (2013), La Saison de l'ombre. Paris: Éditions Grasset \& FasquelleMorrison, Toni. (1988), Beloved, New York: Alfred. A Knopf.

Mohammed, Mahameed (2018). "The Impact of Slavery in Toni Morrison's Beloved: From the Communal to the Individual" In International Journal of Applied Linguistics \& English Literature, November 01, 2018 Volume: 7 Issue: 6, pp.48-51.

Morrison, Toni. (2004). "The Site of Memory" In The Norton Anthology of African-American Literature.(Eds), Henry Louis Gates, JR., Nellie McKay. New York/London: Norton Company.

O'Reilly, Andrea. (2004), Toni Morrison and Motherhood: a Politics of the Heart, Albany: State University of New York.

Poorghorban, Younes. (2020), "Slavery and power in Behn's Social Context; A New Historicist Reading of Oroonoko" In International Journal of Language and Literary Studies, Volume2, Issue 4.

Ramzi, Mehri. (2012). "Magic(al) Realism as postcolonial Device in Toni Morrison's Beloved” In International Journal of Humanities and Social Sciences, vol 2, n.5.

\section{$\underline{A U T H O R S}$ 'BIO}

Dr. Abib SENE, a Senior Lecturer at the Department of English at Cheikh Anta Diop University, graduated at Gaston Berger University (Senegal) and François Rabelais University (France) for his DEA and doctorate degrees. Dr. SËNE is interested in fields of research related to semiotics, literary discourse analysis, Afrocentrism and interculturality.

Dr. Fatoumata KEITA is a Senior Lecturer at the English Department, Université des Lettres et des Sciences Humaines of Bamako, Mali. She graduated from the Université Gaston Berger, Saint-Louis, Sénégal where she earned a Doctorate degree in American literature (2014), a Master's De-gree in American Literature (2007) and a Bachelor's Degree in African Literature (2004). Her teaching and research focus on Africana women's social and political activism as reflected in their autobiographical and fictional writings. Her research interests encompass also gender and postcolo-nial studies, Afrocentricity, African and African American literature with an emphasis on Toni Morrison's works. She was a Fulbright Research scholar at the Columbia University Institute of African Studies in New York City (2017-2018). 